\title{
Alternative sources of revenue in academic libraries
}

\author{
By Anne Beaubien
}

Head of Access Services

University of Michigan

\author{
and Mary Jo Lynch
}

Director

ALA Office for Research and Statistics

From book sales to endowments, every little bit helps.

ditor's Note:The ALA Office for Research and Statistics and the ACRL Task Force on Sources of Revenue in Academic Libraries recently completed a study with financial support from the H.W. Wilson Foundation. Results are described in an 80-page report entitled Alternative Sources of Revenue in Academic Libraries, available from $A L A$. This article is based on the Executive Summary of that report.

The library literature is full of articles about the financial problems of academic libraries. Much is known about such things as rising costs and how to manage budgets to meet them. Little is known, however, about how academic librarians are raising supplementary funds to augment the regular library budget. The extent and nature of those activities is largely undocumented. Neither the National Center for Education Statistics (NCES) nor the Association of Research Libraries (ARL) collect statistics on that topic. Several years ago the ALA Office for Research and the ACRL Task Force decided to explore it. The result is a groundbreaking report that describes a small but important component of the revenue stream of academic libraries. This summary article describes what was done and what was learned.

In April 1990 a four-page questionnaire was mailed to a sample of over 800 academic libraries stratified by the four basic categories in A Classification of Institutions of Higher Education published by the Carnegie Foundation for the Advancement of Teaching: two-year institutions, lib- eral arts colleges, comprehensive colleges and universities, and doctorate-granting institutions. Respondents were asked to describe their revenues in the most recent fiscal year, from five possible "alternative" sources of revenue: services, sales, and special events; computerized catalogs and databases, searching and printing; fines and replacement charges; gifts and grants; and library endowments. The report contains 30 tables and 12 figures that present results in detail.

The two figures shown here summarize those results. Figure 1 (Figure 11 in the report) shows the percentage of respondents reporting various dollar amounts of revenue from all alternative sources. Figure 2 (Figure 12 in the report) shows the percentage of respondents reporting income from all alternative sources as a percentage of operating expenditures; it also indicates the relative importance of those dollars in a library's total budget. The following statements bighlight key findings.

\section{General}

1). Some libraries in each of the four Carnegie categories get some revenue from each of the five alternative sources.

2). Doctorate-granting institutions are most likely to get some revenue from each of the five sources and are most likely toget larger amounts of revenue from any source.

3). The total amount of revenue from all alternative sources varies widely by Carnegie category. Respondents reporting more than $\$ 10,000$ from 
these sources were $93 \%$ of doctorate-granting institutions, $56 \%$ of comprehensive institutions, $35 \%$ of liberal arts institutions, and $24 \%$ of two-year institutions.

4). The percentage of operating expenditures coming from alternative sources is more than $1 \%$ but less than $10 \%$ in most institutions. Public twoyear schools are least likely to report income from these sources.

\section{Services, sales, and special events}

5). Many academic libraries charge users for various services, sales, and special events. Practices vary, however, with the user and the situation in the same library and in different libraries. Sixty-four percent of doctorate-granting institutions reported more than $\$ 10,000$ from this source. On the other hand, only $4 \%$ of two-year schools reported amounts that large.

6). In many cases, libraries do not receive the funds but pass them on to another agency or to the parent institution.

7). The vast majority of libraries in comprehensive, liberal arts, and two-year institutions receive either nothing or less than $\$ 10,000$ a year from services, sales, and special events. In most cases, the amount is less than $1 \%$ of their operating expenditures.

\section{Computerized catalogs and databases, searching and printing}

8). Many academic libraries offer online catalog searching, remote database searching, and CDROM searching and some also offer searching of locally mounted tapes. The percentage of respondents offering these services varies, with doctorategranting institutions showing the highest percentages for all four services.

9). Of the four computerized services, most academic libraries charge only for remote database searching. Funds are not always received by the library, however. The percentage of respondents reporting that they receive the funds is lower than the percentage that charge by at least 12 percentage points in all Carnegie categories and lower by 19 points for comprehensive institutions. Students often get some or all searching free.

10). The vast majority of academic libraries receive either nothing or less than $\$ 10,000$ a year from searching and printing of computerized catalogs and databases.

\section{Fines and replacement charges}

11). Fines are charged in the majority of academic libraries. In over half of the libraries, however, fine monies are not available to the library.

\section{Figure I}

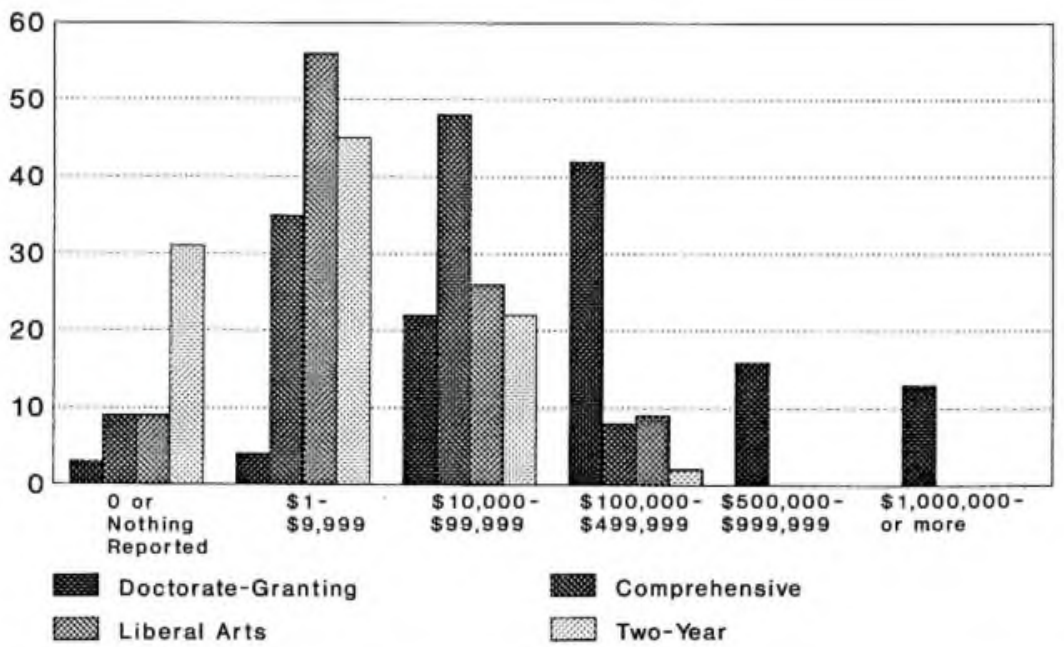

Figure 1. Percentage of respondents (vertical) reporting various dollar amounts of revenue from all alternative sources (horizontal). 


\section{Figure 2}

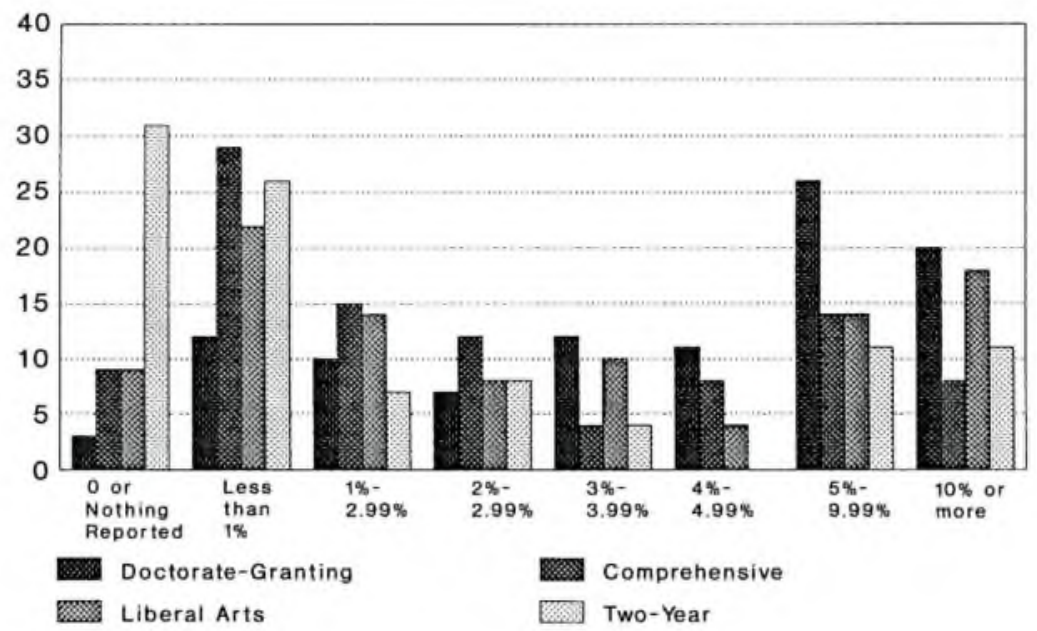

Figure 2. Percentage of respondents reporting income from all alternative sources (vertical) as a percentage of operating expenses (horizontal).

12). Replacement costs are an even more common charge. In this case, the dollars are usually available to the library.

\section{Gifts and grants}

13). Doctorate-granting institutions are more likely to receive gifts and grants from any of the nine sources listed on the questionnaire.

14). Gifts and grants were more likely to be a source of $\$ 10,000$ or more than any other type of alternative sources studied and more likely to constitute more than $1 \%$ of operating expenditures.

\section{Library endowments}

15). Seventy-five percent of responding libraries in doctorate-granting institutions reported having an endowment but only $40 \%$ of comprehensive institutions have them, $27 \%$ of liberal arts colleges, and $9 \%$ of two-year colleges.

16). Most library endowments are less than $\$ 1$ million. However, $32 \%$ of respondents in doctorate-granting institutions reported endowments of more than $\$ 1$ million.

17). Only $2 \%$ of two-year institutions reported revenue of over $\$ 10,000$ from interest or endowment. Amounts of that size were reported by $54 \%$ of doctorate-granting institutions, $12 \%$ of comprehensive institutions, and $14 \%$ of liberal arts institutions.

18). Endowment interest constitutes more than $2 \%$ of operating expenditures in $18 \%$ of doctorategranting institutions, $8 \%$ of comprehensive institutions, $17 \%$ of liberal arts colleges, and $2 \%$ of twoyear colleges.

\section{Fundraising - financial development}

19). Well over half of doctorate-granting institutions were involved in some kind of library fundraising in the three years preceding spring of 1990 , but considerably fewer institutions were so involved in the other Carnegie categories.

20). The percentage of institutions reporting the presence of professionals devoted to library fund raising is relatively small for all Carnegie categories except doctorate-granting institutions. Even for those institutions, only $49 \%$ reported such a person paid from the library budget and only $36 \%$ reported someone paid from the institutional budget.

It was hard to do research on alternative sources of revenue because of a lack of agreement in the library community regarding financial terminology. Despite that, the study provides baseline data 
that show how each of these five sources fits into the revenue picture in each of the four Carnegie categories. The information should be useful as librarians plan activities in this arena and respond to suggestions from campus administrators.
Alternative Sources of Revenue in Academic Libraries (ISBN: 0-8389-5742-0) is available for $\$ 8$. Write to: Order Department, American Library Association, 50 E. Huron Street, Chicago, IL 60611.

\section{Potential money savers}

While the survey on Alternative Sources of Revenue is helpful for indicating other areas of revenue, libraries are also looking for ways to cut costs. We thought readers might find this list of money-saving ideas by the University of California, Irvine's, Library Management Advisory Council and Budget Planning Task Force (first appearing in UCI Library Items, August 12, 1991) of interest. All the ideas are in the "preliminary consideration stage" and library staff are aware that some suggestions directly affect the students. "Since UCI has just undergone $a 40 \%$ increase in tuition and fees, these suggestions will be subject to intense scrutiny ... both in the Library and campus administration. Here are the top 18 ideas, in no particular order." form).

1) Raise photocopy charges (including micro-

2) Charge public for printing MELVYL/CDROM.
3) Raise fee for Friends of Library card.

4) Increase lost card fee.

5) Reduce open hours.

6) Set time for holding positions vacant.

7) Reduce Library Security Monitor (LSM) hours.

8) Reduce binding.

9) Reduce targeting volumes. fiche.

10) Stop producing and sending Serials Lists on

11) Replace voice mail with phone answering machines.

12) Reduce costs for librarian searches.

13) Reduce professional development travel.

14) Reduce administrative travel.

15) Eliminate book title system (BTS).

16) Introduce vending machines.

17) Reduce/eliminate duplication service.

18) Students pick up duplication costs for $\mathrm{Hu}-$ manities 75 materials.

\section{"Some librarians decide to consolidate their business with one}

serials vendor because they appreciate the benefits of dealing with a single representative. We're consolidating as many titles as we can through Faxon for an even more simple reason.

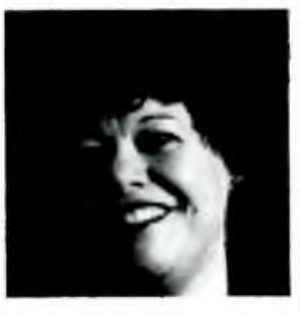

\section{I've never asked Faxon for anything I haven't gotten."}

- Dina Glambi, Head of AcQuisitions and Serials, KENT STATE UNIVERSITY

Helping you manage your world of information. 